\title{
Development of more effective biosurfactants for enhanced oil recovery
}

\section{Semi-Annual Report}

Report Start Date: October 1, 2000

Report End Date: March 31, 2001

M. J. McInerney, H. Mouttaki, M. Folmsbee, R. Knapp, D. Nagle.

Date of Report: April 30, 2001

DE-AC26-98BC15113

Department of Botany and Microbiology

University of Oklahoma

770 Van Vleet Oval

Norman, OK 73019-0245 


\section{Disclaimer}

This report was prepared as an account of work sponsored by an agency of the United States Government. Neither the government nor any agency thereof, nor any of their employees, makes any warranty express or implied, or assumes any legal liability or responsibility for the accuracy, completeness, or usefulness of any information, apparatus, product or processes disclosed, or represents that its use would not infringe privately owned rights. Reference herein to any specific commercial product, process or service by trade name, trademark, manufacturer, or otherwise does not necessarily constitute or imply its endorsement, recommendation, or favoring by the United States Government or any agency thereof. The views and opinions of authors expressed herein do not necessarily state or reflect those of the United States Government or any agency thereof. 


\section{TABLE OF CONTENTS}

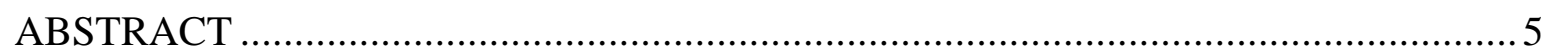

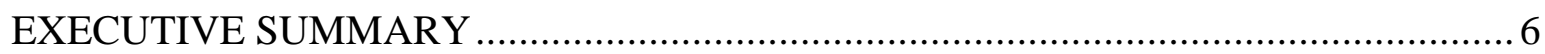

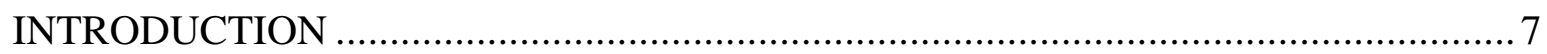

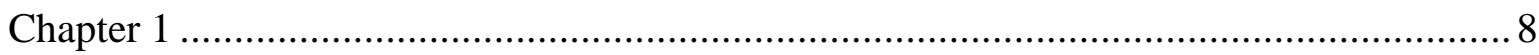

Bacillus mojavensis JF-2 growth and biosurfactant synthesis under anaerobic

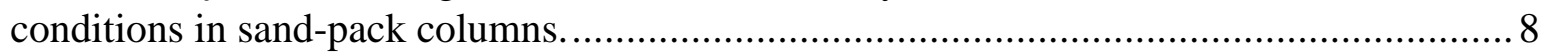

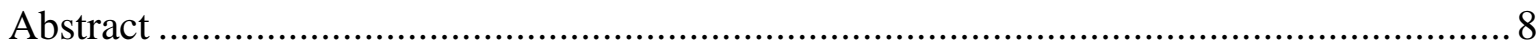

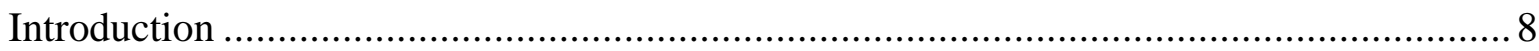

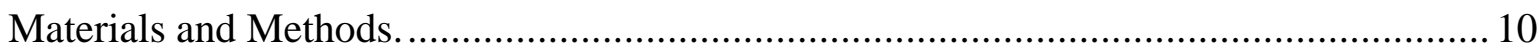

Microorganisms and growth conditions .................................................................. 10

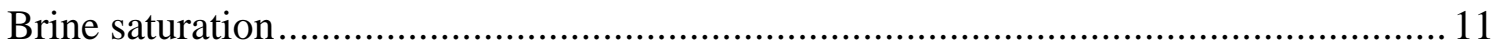

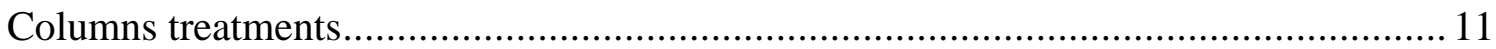

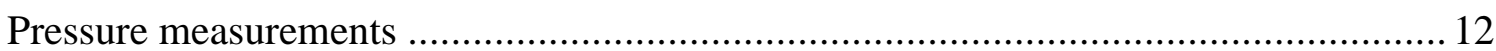

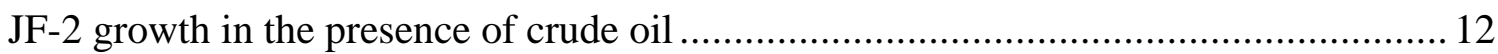

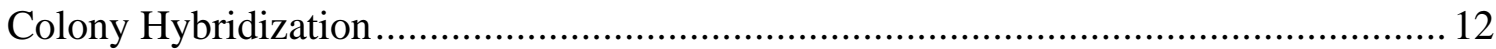

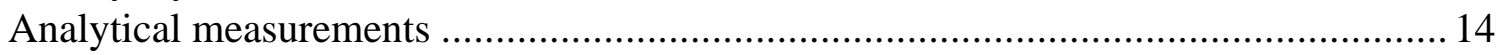

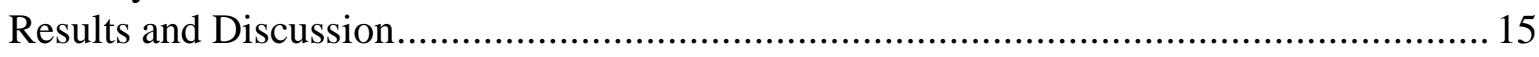

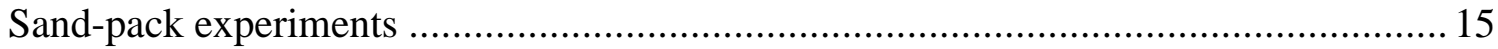

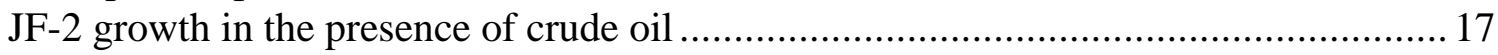

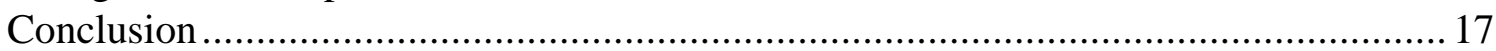

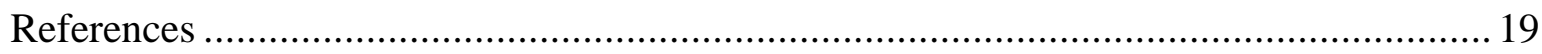

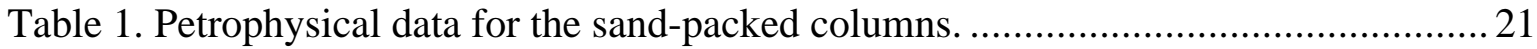

Table 2. Change in pressure in sand-packed columns after inoculation.............................22

Table 3. Substrate consumption and product formation after growth of JF-2 in

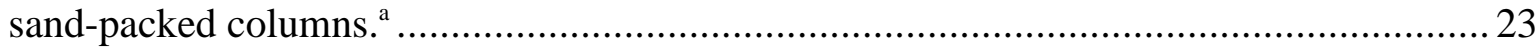

Table 4. Effect of sand, oil and competing organisms on the metabolic activity of

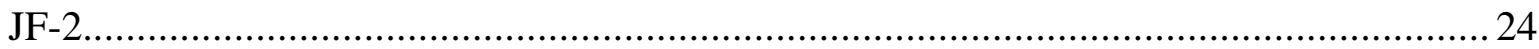

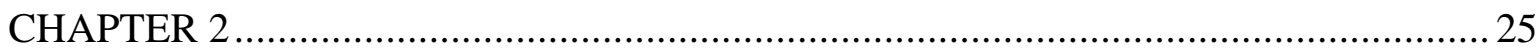

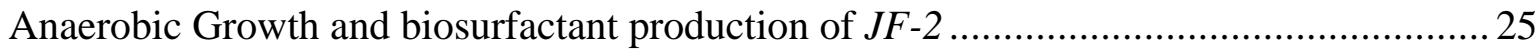

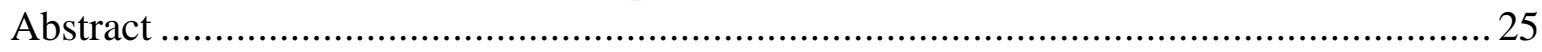

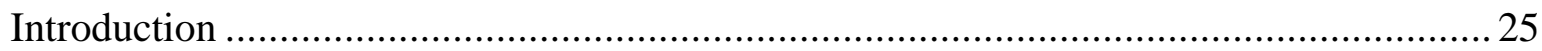

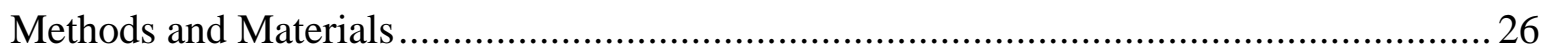

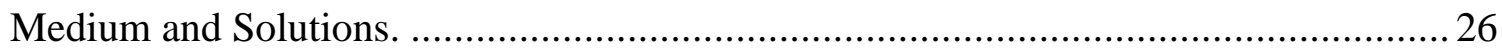

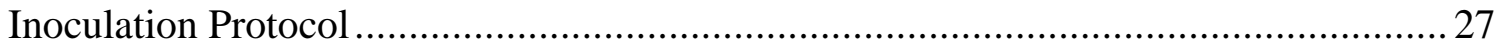

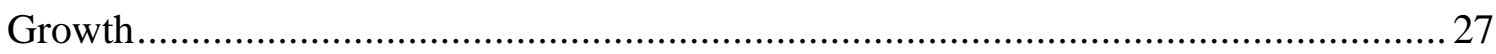

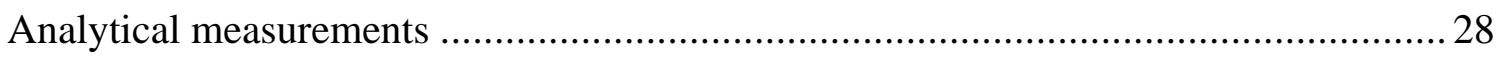

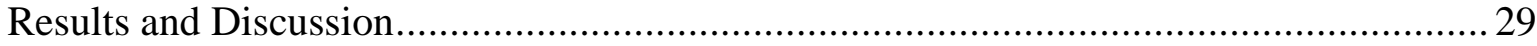

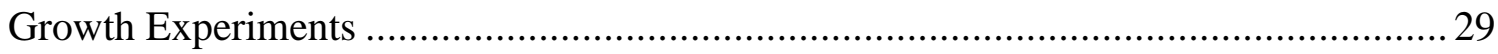

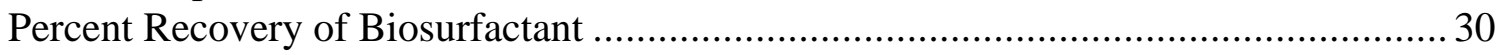


The effect of medium additions on biosurfactant production............................... 30

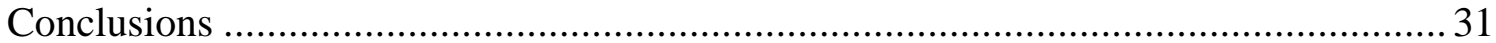

References ............................................................................................... 32

Table 5. The effect of different carbohydrates on the growth rate of JF-2 in $\mathrm{ME}_{2}$. The molarity of the Maltrin sugars was calculated assuming an average molecular

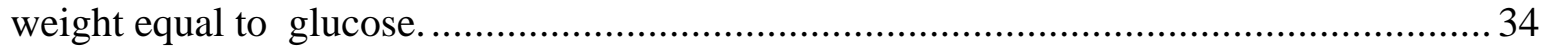

Table 6. Molar growth yields of JF-2 with different carbohydrates.............................. 35

Table 7 . The amount of surfactin recovered by acid precipitation and methanol extraction in three replicate twenty-ml samples .................................................... 36

Table 8 . Biosurfactant production by JF-2 with and without Proteose peptone 2 added to the medium after 18 days of incubation under anaerobic conditions. ................. 37 


\begin{abstract}
Bacillus mojavensis JF-2 (JF-2) grew and synthesized biosurfactant under anaerobic conditions in sand-pack columns in the presence of other competing organisms. The surface tension of the column effluent was $38 \mathrm{mN} / \mathrm{m}$ when the columns were injected with an inoculum size of $10^{8}$ cells $/ \mathrm{ml}$. A slightly higher surface tension $(44 \mathrm{mN} / \mathrm{m})$ was obtained when the inoculum size was $10^{4}$ cells/ml. Growth with glucose gave the fastest growth rate for Bacillus mojavensis JF-2 (JF-2) and monosaccharides in general were the preferred carbon source. The fastest growth rate occurred with a glucose concentration of $77 \mathrm{mM}$. Fructose appeared to produce the highest growth yield. The sample preparation steps used for high performance liquid chromatography (HPLC) analysis resulted in a biosurfactant recovery (from culture supernatant) of about $70 \%$. The presence of Proteose peptone \#2 (PP2) in the medium led to increased biosurfactant production under anaerobic conditions. The biosurfactant was present after extended incubation suggesting that production of biosurfactant was not confined to the exponential phase of growth under anaerobic conditions. Although it is not known exactly when maximum production of biosurfactant occurred, the data suggests that biosurfactant production occurred during stationary phase since maximal growth was reached by $48 \mathrm{hrs}$.
\end{abstract}




\section{EXECUTIVE SUMMARY}

The overall goal of this research is to develop effective biosurfactant production for enhanced oil recovery in the United States. Our current research addressed this goal in two manners. One, by studying the growth and biosurfactant production of Bacillus mojavensis JF-2 (JF-2) in sand packed columns and two, by optimizing the nutrient formulation of the medium. We found that JF-2 grew and synthesized biosurfactant under anaerobic conditions in sand-pack columns in the presence of other competing organisms. We also determined that an inoculum size $\left(10^{8}\right.$ cells $\left./ \mathrm{ml}\right)$ is best for biosurfactant production in the sand columns. Growth with glucose gave the fastest growth rate for Bacillus mojavensis JF-2 (JF-2) and monosaccharides in general were the preferred carbon source. The presence of Proteose peptone \#2 (PP2) in the medium led to increased biosurfactant production under anaerobic conditions. The biosurfactant was present after extended incubation suggesting that production of biosurfactant was not confined to the exponential phase of growth under anaerobic conditions. We now know the type of nutrients and inoculum size needed to produce biosurfactants effectively in systems that mimic actual reservoir conditions. 


\section{INTRODUCTION}

Surfactants are surface active agents that contain both hydrophilic and hydrophobic components. As a result, they can be useful for enhanced oil recovery (EOR). Conventional production technologies are only able to recover approximately 30 to $50 \%$ of oil originally in place. The target of EOR is to increase oil reserves by improving oil recovery. However the large capital or high chemical/energy cost of current EOR technologies limits their application. An alternative technology to improve oil recovery is to use microorganisms, called microbially enhanced oil recovery (MEOR).

MEOR capitalizes on naturally occurring substances and processes; and, since environmental compatibility is becoming an increasingly important factor in the selection of industrial chemicals, MEOR processes could result in both economical and environmentally friendly methods. However, biosurfactants are not a currently feasible alternative to chemically synthesized surfactants as a result of the potentially high production costs.

The purpose of this work is to increase biosurfactant production by Bacillus mojavensis JF-2 by understanding growth and biosurfactant production in the sand packed columns and by optimizing the nutrient formulation. 


\title{
Chapter 1
}

\section{Bacillus mojavensis JF-2 growth and biosurfactant synthesis under anaerobic conditions in sand-pack columns.}

\begin{abstract}
Bacillus mojavensis JF-2 (JF-2) grew and synthesized biosurfactant under anaerobic conditions in sand-pack columns. Biosurfactant production was confirmed using surface tension measurements. The surface tension of the column effluent was $38 \mathrm{mN} / \mathrm{m}$ when the columns were injected with an inoculum size of $10^{8}$ cells $/ \mathrm{ml}$. A slightly higher surface tension $(44 \mathrm{mN} / \mathrm{m})$ was obtained when the inoculum size was $10^{4}$ cells/ml. However, JF-2 was not able to grow in the presence of the particular crude oil used in this experiment.
\end{abstract}

\section{Introduction}

Oil is an essential energy source and continued economic growth increases the demand for oil. Conventional production technologies are able to recover approximately 30 to $50 \%$ of oil originally in place (2). The target of enhanced oil recovery (EOR) is to increase oil reserves by improving oil recovery. However the large capital or high chemical/energy cost of current EOR technologies limits their application (1). An alternative technology to improve oil recovery is to use microorganisms, called microbially enhanced oil recovery (MEOR).

It has been shown that MEOR methods hold promise as an economical alternative to conventional EOR process. MEOR capitalizes on naturally occurring substances and processes; and, since environmental compatibility is becoming an increasingly important factor in the selection of industrial chemicals, MEOR processes could result in both economical and environmentally friendly 
methods. With further research, it may be possible to produce large amounts of useful products such as biosurfactants from inexpensive and renewable resources.

There are a number of ways in which microorganisms may affect the mobilization of oil within reservoirs (10). The accumulation of biomass and polymers synthesized by the microorganisms themselves can plug the most permeable regions redirecting the recovery fluid to previously bypassed zones. The production of polymers can increase the viscosity of the injected fluids and thus positively affect the mobility rates. The capillary number may be increased by a reduction in interfacial tension due to surfactant production. The gas produced by the microorganisms can cause a local repressurization within the reservoir. The production of acids will dissolve the limestone matrices and improve oil recovery by changing the porosity. JF-2 is able to synthesize a biosurfactant significantly decreases both the surface tension and the interfacial tension between oil and water and it is potentially useful in enhanced oil recovery $(4,5,9)$.

In previous experiments, metabolic indicators (such as the loss of glucose, and/or the production of metabolic byproducts) were not detected in the column effluent of sand-pack columns saturated with oil and inoculated with JF-2 ( see previous report). While some glucose loss was detected, it was not possible to associate this loss with microbial growth. No viable bacteria were detected in the effluent. In an effort to clarify the reasons for this, several hypothesis were tested: - JF-2 is not able to grow in a sand environment due to a contact inhibition with the sand.

- The sand contains some competing microorganisms which prevent JF-2 from growing.

- JF-2 growth is inhibited by the presence of particular crude oil that was used. 
The purpose of the following studies was to test these hypothesis to determine what factor was responsible for the inhibition of JF-2 growth. First we determined if JF-2 was able to grow in the sand-pack environment under anaerobic conditions by measuring metabolic by-products synthesized from glucose and by plating the effluent onto medium to see if JF-2 was present. Secondly, we determined if the presence of this particular crude oil was inhibitory to JF-2.

\section{Materials and Methods.}

Microorganisms and growth conditions

Bacillus mojavensis JF-2 (ATCC \# 39307) was grown anaerobically in medium E. Medium E contained (per liter): $2.7 \mathrm{~g} \mathrm{KH}_{2} \mathrm{PO}_{4}, 13.9 \mathrm{~K}_{2} \mathrm{HPO}_{4}, 50 \mathrm{~g}$ $\mathrm{NaCl}, 10 \mathrm{~g}$ glucose, $1 \mathrm{~g}$ yeast extract, $1 \mathrm{~g} \mathrm{NaNO}_{3}, 1 \mathrm{~g}\left(\mathrm{NH}_{4}\right)_{2} \mathrm{SO}_{4}, 30 \mathrm{~g}$ Proteose Peptone \#2, and $10 \mathrm{ml}$ of a metal solution. The metal solution (a modified Wolin's trace metal solution) contained: $1 \mathrm{~g}$ EDTA, $3 \mathrm{~g} \mathrm{MnSO}{ }_{4} \mathrm{H}_{2} \mathrm{O}, 0.1 \mathrm{~g} \mathrm{FeSO} \cdot 7 \mathrm{H}_{2} \mathrm{O}$, $0.1 \mathrm{~g} \mathrm{CaCl}_{2} 2 \mathrm{H}_{2} \mathrm{O}, 0.1 \mathrm{~g} \mathrm{CoCl}_{2} 2 \mathrm{H}_{2} \mathrm{O}, 0.1 \mathrm{~g} \mathrm{ZnSO}_{4} 2 \mathrm{H}_{2} \mathrm{O}, 0.01 \mathrm{~g} \mathrm{CuSO}_{4} \cdot 5 \mathrm{H}_{2} \mathrm{O}, 0.01$ g AlK $\left(\mathrm{SO}_{4}\right)_{2}, 0.01 \mathrm{~g} \mathrm{H}_{3} \mathrm{BO}_{3}, 0.01 \mathrm{~g} \mathrm{Na}_{2} \mathrm{MoO}_{4} \cdot 7 \mathrm{H}_{2} \mathrm{O}, 25 \mathrm{~g} \mathrm{MgSO}_{4}$. Bacterial enumeration was performed by plating onto medium E containing $1.5 \mathrm{~g} / \mathrm{l}$ of agar. The serial dilution was performed using a sterilized solution containing $2.7 \mathrm{~g}$ $\mathrm{KH}_{2} \mathrm{PO}_{4}, 13.9 \mathrm{~g} \mathrm{~K}_{2} \mathrm{HPO}_{4}$, and $50 \mathrm{~g} \mathrm{NaCl}$ (pH of 6.8).

Sand-pack preparation

Plexiglass columns were filled with sand (quartz with a density of 2.65 $\mathrm{kg} / \mathrm{l}$ ) and packed with continuous vibrations to ensure a homogenous packing density and avoid the formation of layers. The columns were sealed with plastic stoppers and a butyl rubber septum was used to allow aseptic and anaerobic additions to the columns and to maintain anaerobic conditions. The ends were capped by using polypropylene filters with a pore size of $20 \mu \mathrm{m}$. 
Each column was weighed before and after packing with sand. It will give the sand weight. Knowing the density of sand, the pore volume was determined by calculated the difference between the column volume and the sand volume. The pore volume was also determined by weighing the columns before and after the brine flooding. From the brine density $\left(\rho_{b}=1.05196\right)$, and the difference in weight before and after the flooding, the liquid pore volume was calculated. These two techniques gave similar estimates for the pore volume that differed by only $1-1.4 \%$ (Table 1 ). To ensure anaerobic conditions, the columns were flushed 3 times with nitrogen gas and then placed in an anaerobic chamber for 24 hours.

\section{Brine saturation}

The columns were injected with brine (degassed nanopure water with 5\% $\mathrm{NaCl}$ using positive pressure of the fluid reservoir to push fluid into the columns. Two pore volumes were injected through the columns to saturate them and remove the gas trapped inside.

\section{Columns treatments}

A $200 \mathrm{ml}$ solution of medium E inoculated with JF-2 was incubated under anaerobic conditions at $40^{\circ} \mathrm{C}$ for 20 hours. The surface tension was $30 \mathrm{mN} / \mathrm{m}$. The cell concentration was determined using a Petroff Hausser counting chamber (1/400 square $\mathrm{mm}, 1 / 50 \mathrm{~mm}$ deep) (3). The cells were pelleted by centrifugation and resuspended in sterile medium $\mathrm{E}$ to give a cell concentration of $10^{4}$ or $10^{8}$ cells $/ \mathrm{ml}$.

Two columns (1 and 2) were treated with one pore volume of medium E which contained a cell concentration of $10^{4}$ cells $/ \mathrm{ml}$. A third column (3) was treated with one pore volume of medium E containing a cell concentration of $10^{8}$ cells/ml. A fourth column (4) was treated with sterile medium E and served as the control. Each column was flooded by using a positive pressure of nitrogen gas to push he liquid into the column. The sand-packs were incubated at $40^{\circ} \mathrm{C}$. 
Pressure measurements

The pressure inside the columns was measured by using a Cole-Parmer digital gauge. JF-2 produces $\mathrm{CO}_{2}$ and $\mathrm{N}_{2}$ as end product of its metabolism, so gas production was used as an indicator of in situ growth (Table 2). When the rate of increase in the gas pressure stopped, the columns were flooded with two pore volumes of brine, and samples were collected into $30 \mathrm{ml}$ syringes. The effluent was collected in $20 \mathrm{ml}$ samples. The liquid effluent was frozen until subsequent analysis.

JF-2 growth in the presence of crude oil

Serum bottles were filled with $50 \mathrm{~g}$ of sand and flushed with nitrogen for 5 minutes to ensure anaerobic conditions. Each bottle received $30 \mathrm{ml}$ of medium $\mathrm{E}$ and $1 \mathrm{ml}$ of oil. The bottles were inoculated with JF-2 and incubated for 20 hours at $40^{\circ} \mathrm{C}$. The positive controls consisted of inoculating medium E with JF-2 in the absence of sand and oil. The negative control consisted of an uninoculated medium with sand and oil. The sand was previously sterilized at $120^{\circ} \mathrm{C}$ during 20 minutes. The experiment was done in triplicate

Balch tubes containing $20 \mathrm{ml}$ of medium E supplemented with $1 \mathrm{ml}$ of crude oil were inoculated with JF-2. The oil was previously sterilized at $120^{\circ} \mathrm{C}$ during 20 minutes. The positive control consisted of tubes without oil. The tubes were all kept under anaerobic conditions. This was performed in triplicate.

\section{Colony Hybridization}

Cells were transferred to a nylon membrane from a petri dish by placing the nylon membrane on the surface of the petri dish. The cells were then lysed by placing the membrane in a solution of $0.5 \mathrm{~N}$ of $\mathrm{NaOH}$, and allowed to stand for 10 minutes at room temperature. The membrane was transferred first to a filter paper soaked with $0.5 \mathrm{M}$ Tris $\mathrm{HCl}(\mathrm{pH} 7.5)$ for 5 minutes, then to a filter paper soaked 
with a solution containing $0.5 \mathrm{M}$ Tris $\mathrm{HCl}(\mathrm{pH} 7.5)$ and $1.5 \mathrm{M} \mathrm{NaCl}$ for 5 minutes, and finally transferred to a filter paper soaked with $2 \mathrm{xSSC}$ solution (20xSSC solution is $173.3 \mathrm{~g}$ of $\mathrm{NaCl}$ and $88.2 \mathrm{~g}$ of sodium citrate per liter at a $\mathrm{pH} 7.8$ ). To immobilize the DNA onto the membrane, the membrane was baked under vacuum for 2 hours at $80^{\circ} \mathrm{C}$.

The membrane was placed in a hybridization glass tube (Fisher Biotech) containing $20 \mathrm{ml}$ prehybridization solution (DIG Eazy Hyb, Boehringer Mannheim) per $100 \mathrm{~cm}^{2}$ of membrane surface area, and incubated in Hybridization Incubator (Fisher Biotech) at $37-42^{\circ} \mathrm{C}$ for 2 hours. The prehybridization solution was discarded and the prehybridization solution containing the labeled probe srfA1 $(5-25 \mathrm{ng} / \mathrm{ml})$ was added, and incubated in Hybridization Incubator at $37-42^{\circ} \mathrm{C}$ overnight. At the end of the hybridization, the hybridization solution was poured into a tube. The membrane was washed in $2 \mathrm{x}$ washing solution (300 mM NaCl, $30 \mathrm{mM}$ sodium citrate, $0.1 \% \mathrm{SDS}, \mathrm{pH} 7.0$ ) at room temperature for $10 \mathrm{~min}$. The membrane was washed again in $0.5 \mathrm{x}$ washing solution (75 mM NaCl, $7.5 \mathrm{mM}$ sodium citrate, $0.1 \% \mathrm{SDS}, \mathrm{pH} 7.0)$ at $68^{\circ} \mathrm{C}$ for 30 $\min$.

After hybridization and post-hybridization washes, the membrane was equilibrated in washing buffer (100 mM maleic acid, $150 \mathrm{mM} \mathrm{NaCl}$; $\mathrm{pH} 7.5 ; 0.3 \%$ (v/v) Tween $\left.{ }^{\circledR} 20\right)$ for 1 minute. The membrane was blocked by gently agitating it in blocking solution (100 mM maleic acid, $150 \mathrm{mM} \mathrm{NaCl}$; pH 7.5; 1\% (w/v) Blocking reagent [Boehringer Mannheim]) for 30-60 minutes. The blocking solution was removed and the membrane was incubated in the antibody solution (the Anti-Digoxigenin-AP in blocking solution [1:100000 v/v], Boehringer Mannheim) for 30 minutes. After the antibody solution was discarded, the membrane was washed in washing buffer for 30 minutes. The washing buffer was removed and the membrane was equilibrated in detection buffer (100 mM Tris$\mathrm{HCl}, 100 \mathrm{mM} \mathrm{NaCl} ; \mathrm{pH} 9.5$ ) for two minutes. The membrane was placed between 
two sheets of acetate (PhotoGene Development Folders, Gibco BRL) and $0.5 \mathrm{ml}$ (per $100 \mathrm{~cm}^{2}$ ) of the Chemiluminescent substrate $\left(\mathrm{CSPD}^{\circledR}\right.$ 1:100 in detection buffer, Boehringer Mannheim) was then added on top of the membrane, scattering the drops over the surface of the membrane. With a damp tissue, the top sheet of plastic was wiped gently to remove any bubbles present under the sheet and to create a liquid seal around the membrane. The filter was incubated for 5 minutes. The semi-dry membranes were sealed in acetate sheets. The membrane was incubated at $37^{\circ} \mathrm{C}$ for 15 minutes. For detection of the Chemiluminescent signal, the membrane was exposed to Lumi-Film (Boehringer Mannheim) for 15-20 minutes.

Analytical measurements

The surface tension was measured using a Fisher Tensiometer model 215. The surface tension of nanopure water was measured as a standard $(73 \mathrm{mN} / \mathrm{m})$. All the samples were measured at room temperature.

The concentration of glucose was measured by phenol sulfuric method (3). The absorbance was read at $488 \mathrm{~nm}$ against the blank prepared without glucose. The concentrations of glucose were determined in the samples from a standard curve prepared by plotting the absorbance of standards versus the concentration of glucose.

Nitrate concentrations were determined by using a Dionex Ion Chromatography system with an AS4A-SC 4-mm particle-size column, a model CD 20 conductivity detector, and a mobile phase of $1.8 \mathrm{mM}$ sodium carbonate and $1.7 \mathrm{mM}$ sodium bicarbonate delivered at $2 \mathrm{ml} / \mathrm{min}$.

Acetate and butanediol concentrations were determined using a gas chromatography equipped with a flame ionization detector and a glass column. The samples as well as the standards were diluted in a solution of $30 \mathrm{mM}$ of oxalic acid. 
The concentration of biosurfactant in the samples was quantified by HPLC analysis. A C18 column was used with a mobile phase of $70 \%$ methanol and $30 \%$ of $10 \mathrm{mM}$ phosphate buffer. The HPLC was run at a flow rate of $1 \mathrm{ml} / \mathrm{min}$ and the injection volume was $20 \mu \mathrm{l}$. A UV detector was used with a wavelength set at 210 $\mathrm{nm}$. Sample preparation is described in the previous chapter of this report.

\section{Results and Discussion}

Sand-pack experiments

The first experiment was conducted to determine if JF-2 was able to grow and produce biosurfactant in a sand environment under anaerobic conditions. It was also important to determine if inoculum size influenced biosurfactant production. The columns were inoculated with two different cell concentrations of JF-2: two columns ( 1 and 2) were treated with a cell concentration of $10^{4}$ cells/ml and a third column (3) was treated with a cell concentration of $10^{8}$ cells/ml. The fourth column was treated with uninoculated medium $\mathrm{E}$ and served as a control. After two days of incubation, there was not any further increase in pressure within the columns (Table 2). After 5 days of incubation, the columns were flooded with brine. The first column was allowed to incubate for a longer period of time (11 days) in order to determine if a longer incubation time was necessary for biosurfactant production.

The surface tension measured in the two first columns was reduced to 44 $\mathrm{mN} / \mathrm{m}$, which indicated the production of biosurfactant. The surface tension of the third column where the inoculum size was higher, $10^{8}$ cells $/ \mathrm{ml}$ reached a value of $38 \mathrm{mN} / \mathrm{m}$. HPLC analysis was not able to detect the presence of biosurfactant. Significant depletion of glucose and nitrate was observed in all the columns indicating metabolic activity. This suggested that JF-2 grew and metabolized its substrates inside the sand-pack columns. The end -product analysis revealed the production of acetate and butanediol in all the columns, even in the uninoculated 
column (Table 3), potentially due to contamination. The metabolic activity in column 4 was probably due to organisms present in the sand grains.

The effluent from each column was plated onto medium $\mathrm{E}$ to determine the viable cell concentration in the effluent of each column. The effluent cell concentration was $11.5 \times 10^{4}, 8 \times 10^{4}, 15 \times 10^{5}$ and $16.4 \times 10^{3}$ cells/ml for columns $1,2,3$ and 4 , respectively. The cells were transferred onto a membrane and lysed to expose the DNA and to hybridize it with a probe corresponding to one of the genes involved in the biosynthesis of biosurfactant to determine if JF-2 was growing inside the columns. The concentraiton of JF-2 in the column effluent was $8.5 \times 10^{3}$ for the column $1,5 \times 10^{3}$ for the column $2,8 \times 10^{4}$ for column 3 and $4 \times 10^{2}$ for column 4. This showed that JF-2 represented about 2 to $7 \%$ of the viable cell population and the presence of this other bacteria did not prevent JF-2 from growing and synthesizing its biosurfactant. The surface tension in the fourth column did not decrease and the number of JF-2 cells observed was very low. These data suggest that the cell concentration is important for biosurfactant synthesis and that biosurfactant production depends on the presence of JF-2.

Previous work (under aerobic conditions) showed that biosurfactant synthesis in JF-2 occurs during the exponential phase of growth and when cells reach the stationary phase the biosurfactant concentration starts to decrease until it completely disappears from the culture broth $(5,7,8)$. However as shown with the first column, which was incubated for 11 days, the surface tension was the same as that found in the column incubated for only 5 days of incubation. The anaerobic conditions may prevent the internalization of the biosurfactant molecules by the microorganisms.

The spatial distribution of metabolic end-products such as glucose, nitrate, acetate and butanediol was examined to determine if these products are uniformly present or present along a gradient within the column. The columns have a total liquid volume of about $68 \mathrm{ml}$. During the brine flood, the effluent was collected in 
3 separate samples $(20 \mathrm{ml})$, each corresponding to about a third of the liquid volume of the column. The analyses showed that the distribution of products along the column decreased slightly (Table 3). For example, in column 1, the first sample had a glucose concentration of $2.9 \mathrm{mM}$ and the second sample had a glucose concentration of $2.5 \mathrm{mM}$. Similarly, the acetate concentration at the first sample was $17.4 \mathrm{mM}$ and $12.8 \mathrm{mM}$ in the second sample. The butanediol concentration was $7.6 \mathrm{mM}$ and $6.1 \mathrm{mM}$ respectively. These data suggest uniform growth of JF-2 throughout the column.

JF-2 growth in the presence of crude oil

From the data given above, it was determined that the presence of sand or competing microorganisms did not inhibit JF-2 growth. So, the second experiment was conducted to determine if the particular oil used in the experiment was actually responsible for inhibiting growth of JF-2. As JF-2 was isolated from oil-field injection brine $(5,7)$ it was evident that JF-2 was able to grow in the presence of crude oil. However, in this case, the oil in use did appear to inhibit growth of JF-2. Each time oil was added to the medium inoculated with cells, no bacterial growth occurred and no metabolic activity was detected since neither glucose nor nitrate were depleted (Table 4). Since no growth was detected in bottles using sterilized sand and oil, the inhibition was not due to competition from other microorganisms. This data confirmed that that particular crude oil used in the sand packs inhibited JF-2 growth.

\section{Conclusion}

JF-2 is able to grow under anaerobic conditions in a sand environment and produce its biosurfactant. These qualities make it suitable for understanding the MEOR processes in laboratory sand-pack columns. It is able to synthesize its biosurfactant at a detectable level if the inoculum size is above $10^{8}$ cells $/ \mathrm{ml}$. However the experiment revealed that the particular crude oil used in our 
experiment inhibited JF-2 from growing, and this phenomenon was not due to a competing microorganism. However, other crude oils can be used which are not inhibitory. 


\section{References}

1. Bryant, R. S., J. Douglas.1987. Evaluation of microbial systems in porous media for enhanced oil recovery. Paper presented at the 1987 SPEIinternational Symposium of Oilfield Chemistry.

2. Churchill, S. A., R. A. Griffin, L. P Jones, P. F. Churchill. 1995. Biodegradation and bioremediation. Biodegradation rate, enhancement of hydrocarbons by an oleophilic fertilizer and rhamnolipid biosurfactant. $J$. Environ. Qual. 24: 19-28.

3. Gerhardt, Murray, Costilow, Nester, Wood, Krieg and Philips. 1981.ASM. Manual of methods for general bacteriology. American Society for Microbiology, Washington, D. C.

4. Jahaveri, M., G. E. Jenneman, M. J. McInerney, R. M. Knapp. 1985. Anaerobic production of biosurfactant by Bacillus licheniformis JF-2. Appl. Environ. Microbiol. 50: 698-700.

5. Jenneman, G. E., M. J. McInerney, R. M. Knapp, J. B. Clark, J. M. Ferro, D. E. Revus, D. E. Menzie. 1983. A halobacter, biosurfactant-producing Bacillus species potentially useful for enhanced oil recovery. Dev. Ind. Microbiol. 24: 485-492.

6. Lin, S-C., M. A. Minton, M. M. Sharma, G. Georgiou. 1994. Structural and immunological characterization of a biosurfactant produced by Bacillus licheniformis JF-2. Appl. Environ. Microbiol. 60: 31-38.

7. Lin, S. C. 1996. Biosurfactants: Recent advances. J. Chem. Tech. Biotechnol.66: 109-120.

8. Lin, S-C., K-G Lin, C.C. Lo, Y-M. Lin. 1998. Enhanced biosurfactant production by a Bacillus licheniformis mutant. Enzym. Microbiol .Technol. 23: 267-273. 
9. McInerney, M. J., M. Jahaveri, D. P Nagle. 1990. Properties of the biosurfactant produced by Bacillus licheniformis strain JF-2. J. Ind. Microbiol. 5: 95-102.

10. Yonebayashi, H., S. Yoshida, K. Ono, H. Enomoto. 2000. Screening of microorganisms for microbial enhanced oil recovery processes. Sekiyu Gakkaishi. 1: 59-69. 
Table 1. Petrophysical data for the sand-packed columns.

\begin{tabular}{cccccc}
\hline Column \# & $\begin{array}{c}\text { Weight of } \\
\text { sand }(\mathrm{g})\end{array}$ & $\begin{array}{r}\text { Volume of } \\
\text { sand }\left(\mathrm{cm}^{3}\right)\end{array}$ & $\begin{array}{l}\text { Pore volume } \\
\left(\mathrm{cm}^{3}\right)\end{array}$ & $\begin{array}{c}\text { Weight of } \\
\text { brine }(\mathrm{g})\end{array}$ & $\begin{array}{c}\text { Pore volume } \\
\left(\mathrm{cm}^{3}\right)\end{array}$ \\
\hline 1 & 357.02 & 134.7245 & 67.1 & 71.1 & 67.6 \\
2 & 358.98 & 135.4642 & 66.3 & 70.5 & 67.0 \\
3 & 354.93 & 133.9358 & 67.9 & 72.2 & 68.6 \\
4 & 353.29 & 133.4260 & 68.4 & 72.9 & 69.3 \\
\hline
\end{tabular}


Table 2. Change in pressure in sand-packed columns after inoculation.

\begin{tabular}{cccccc}
\hline Column \# & & \multicolumn{3}{c}{ Time } \\
& 20 hours & 48 hours & 4 days & 5 days & 11 days \\
\hline 1 & 3.6 & 7.1 & 6.4 & 6.4 & 6.2 \\
2 & 3.5 & 9.6 & 8.5 & 8.0 & \\
3 & 8.7 & 11.7 & 11.3 & 10.6 & \\
4 & 1.7 & 7.4 & 5.2 & 5.2 & \\
\hline
\end{tabular}


Table 3. Substrate consumption and product formation after growth of JF-2 in sand-packed columns. ${ }^{a}$

\begin{tabular}{|c|c|c|c|c|c|c|}
\hline Column \# & $\begin{array}{l}\text { Effluent } \\
\text { Fraction }\end{array}$ & $\begin{array}{l}\text { Surface } \\
\text { Tension } \\
(\mathrm{mN} / \mathrm{m})\end{array}$ & $\begin{array}{c}\text { Glucose } \\
(\mathrm{mM})\end{array}$ & $\begin{array}{l}\text { Nitrate } \\
(\mathrm{mM})\end{array}$ & $\begin{array}{l}\text { Acetate } \\
(\mathrm{mM})\end{array}$ & $\begin{array}{c}\text { Butanedio } \\
(\mathrm{mM})\end{array}$ \\
\hline \multirow[t]{2}{*}{1} & First & 44 & 2.9 & ND & 17.4 & 7.6 \\
\hline & Middle & 47 & 2.5 & ND & 12.8 & 6.1 \\
\hline \multirow[t]{2}{*}{2} & First & 44 & 4.8 & ND & 18.4 & 5.9 \\
\hline & Middle & 48 & 3.4 & ND & 16.5 & 5.5 \\
\hline \multirow[t]{2}{*}{3} & First & 38 & 3.3 & ND & 17.6 & 9.0 \\
\hline & Middle & 41 & 3.3 & ND & 18.8 & 8.4 \\
\hline \multirow[t]{2}{*}{4} & First & 60 & 4.2 & ND & 16.9 & 4.9 \\
\hline & Middle & 58 & 2.8 & ND & 13.3 & 3.0 \\
\hline
\end{tabular}

${ }^{\mathrm{a}}$ Initial glucose concentrations were 59 to $64 \mathrm{mM}$ and initial nitrate concentration was 15 to $16 \mathrm{mM}$. 
Table 4. Effect of sand, oil and competing organisms on the metabolic activity of JF-2.

\begin{tabular}{lcccc}
\hline $\begin{array}{l}\text { Treatment } \\
\text { concentration }(\mathrm{mM})\end{array}$ & \multicolumn{2}{l}{ Glucose concentration $(\mathrm{mM})$} & Nitrate & \\
\hline & Initial & Final & Initial & Final \\
\hline JF-2 & 53.7 & 20 & 13.8 & 0.5 \\
JF-2 + oil & 53.5 & 51 & 14.7 & 13.8 \\
JF-2 + sand & 53.6 & 18 & 14.5 & 1.3 \\
JF-2 + sand and oil & 52 & 53 & 14.7 & 13.8 \\
JF-2 + sterile sand & 51.3 & 26 & 14.9 & 2.8 \\
JF-2 + sterile sand & 51 & 54 & 13 & 15 \\
$\quad$ and oil & & & & 15.7 \\
Sand + oil & 55 & 48 & 16 & \\
\hline
\end{tabular}




\title{
CHAPTER 2
}

\section{Anaerobic Growth and biosurfactant production of $J F-2$}

\begin{abstract}
Growth with glucose gave the fastest growth rate for Bacillus mojavensis JF-2 (JF-2) and monosaccharides in general were the preferred carbon source. The fastest growth rate occurred with a glucose concentration of $77 \mathrm{mM}$. Fructose appeared to produce the highest growth yield. The sample preparation steps used for high performance liquid chromatography (HPLC) analysis resulted in a biosurfactant recovery (from culture supernatant) of about $70 \%$. The presence of Proteose peptone \#2 (PP2) in the medium led to increased biosurfactant production under anaerobic conditions. The biosurfactant was present after extended incubation suggesting that production of biosurfactant was not confined to the exponential phase of growth under anaerobic conditions. Both surface tension reduction data and HPLC analysis failed to detect significant amounts of biosurfactant during exponential growth. However, after 18 days, a significant amount was detected in the culture supernatant of medium containing Proteose peptone. Although it is not known exactly when maximum production of biosurfactant occurred, the data suggests that biosurfactant production occurred during stationary phase since maximal growth was reached by $48 \mathrm{hrs}$.
\end{abstract}

\section{Introduction}

Javahari et. al, (1), reported both the successful growth of, and biosurfactant production by, JF-2 under anaerobic conditions. This biosurfactant effectively reduces both surface tension and interfacial tension and is potentially useful in enhanced oil recovery $(2,3,4)$. Consequently, it is important to 
understand the factors that affect the production of biosurfactant. To do so, first requires the improvement of growth since biosurfactant production is linked to growth $(1,2,5)$. The purpose of the following study was to enhance anaerobic growth of JF-2 (ATCC 39307), with the ultimate goal of improving biosurfactant production under anaerobic conditions.

Previously we reported that the addition of Proteose peptone improved the growth of JF-2 under anaerobic conditions. A method for quantifying biosurfactant using HPLC was also developed. With the HPLC method and with surface tension measurements, it was now possible to determine when biosurfactant is produced and the effect of medium additions on biosurfactant production. Although it had not been possible at this time to exactly determine when biosurfactant is maximally produced, the effect of some medium additions on biosurfactant production has been determined.

\section{Methods and Materials}

Medium and Solutions.

A modified medium $\mathrm{E}\left(\mathrm{ME}_{2}\right)$ was used. $\mathrm{ME}_{2}$ contained the following components per 900 mls: TES buffer (N-tris(hydroxymethyl)methyl-2aminoethansulfonic acid) (22.9g); sodium chloride (50g); sucrose (10g); yeast extract (1g); sodium nitrate (1g); dibasic potassium phosphate (1.0g); ammonium sulfate $(1 \mathrm{~g})$; magnesium sulfate $(0.25 \mathrm{~g})$ and $100 \mathrm{mls}$ of a metal solution. The metal solution was a modification of Wolins metal solution (6) and was contained the following components per liter: EDTA (1g); $\mathrm{MnSO}_{4} \cdot \mathrm{H}_{2} \mathrm{O}(3 \mathrm{~g}) ; \mathrm{FeSO}_{4} \cdot 7 \mathrm{H}_{2} \mathrm{O}$ (0.1g); $\mathrm{CaCl}_{2} \cdot 2 \mathrm{H}_{2} \mathrm{O}(0.1 \mathrm{~g}) ; \mathrm{CoCl}_{2} \cdot 2 \mathrm{H}_{2} \mathrm{O}(0.1 \mathrm{~g}) ; \mathrm{ZnSO}_{4} \cdot 7 \mathrm{H}_{2} \mathrm{O}(0.1 \mathrm{~g}) ; \mathrm{CuSO}_{4} \cdot 7 \mathrm{H}_{2} \mathrm{O}$ (0.01g); $\mathrm{H}_{3} \mathrm{BO}_{4}(0.01 \mathrm{~g}) ; \mathrm{Na}_{2} \mathrm{MO}_{4} \cdot 2 \mathrm{H}_{2} \mathrm{O}(0.01 \mathrm{~g}) ; \mathrm{AlK}\left(\mathrm{SO}_{4}\right)_{2}(0.01 \mathrm{~g}) . \mathrm{ME}_{2}$ also contained 3\% Proteose peptone \#2. Cystein hydrochloride was added in the concentration of $0.025 \%$ (wt/vol). 
Various concentrations of glucose and other sources of carbohydrate were prepared at concentration ten times the intended final concentration. To create anaerobic conditions, the sugar solution was boiled under a stream of nitrogen gas and poured into a serum bottle, which was also flushed with nitrogen gas. The headspace was composed of nitrogen. In the case of the corn syrup derivatives (Maltrin), an average molecular weight (MW) of glucose was assumed to determine molarity.

\section{Inoculation Protocol}

A serum bottle with $100 \mathrm{ml}$ of anaerobic $\mathrm{ME}_{1}$ (ME without any additions) was inoculated directly from a freshly grown (24h) plate of B. mojavensis strain JF-2. The serum bottle was allowed to incubate for 24 hours at $40^{\circ} \mathrm{C}$. From this culture a $5 \mathrm{ml}$ inoculum (1\%) was used for each serum bottle. A $1 \%$ inoculum was used.

\section{Growth}

All tubes and serum bottles were incubated at $40^{\circ} \mathrm{C}$ in a stationary incubator. Growth was measured using a spectrophotometer with the wavelength set at $600 \mathrm{~nm}$. Growth was also measured by dry weight analysis. The sample was centrifuged at $8000 \mathrm{xg}$. The pellet was re-suspended in $10 \mathrm{ml}$ of $10 \mathrm{mM}$ phosphate buffer and re-centrifuged to remove medium components from the cell pellet. The pellet was then re-suspended in $2 \mathrm{ml}$ of $10 \mathrm{mM}$ phosphate buffer and poured into a pre-weighed aluminum pan. An uninoculated sample was treated similarly and the final dry weight of the uninoculated residue was subtracted from the dry weight obtained with the cell pellet. The pans were dried for $6 \mathrm{hrs}$ in a drying oven at $70^{\circ} \mathrm{C}$. 


\section{Analytical measurements}

The surface tension was measured using a De Nuoy ring tensiometer. Three $\mathrm{ml}$ of the culture supernatant was allowed to equilibrate at room temperature in small plastic weigh pans before the surface tension was recorded. Nanopure water was used as the high surface tension standard $(\sim 73$ dynes $/ \mathrm{cm})$ and Micro-90 detergent was used as the low standard ( 27 dynes $/ \mathrm{cm})$.

The concentration of glucose was measured by phenol sulfuric method (8).

The extraction efficiency was used to determine the degree to which biosurfactant is recovered from the growth medium. This value was used as a correction factor to determine the actual amount present in the medium. Medium was prepared as described above. Surfactin was added in the concentration of 0.5 $\mathrm{mg} / \mathrm{ml}$ to $60 \mathrm{ml}$ and an identical amount of medium without surfactin served as the control. In each case, the medium was autoclaved and allowed to cool before the addition of surfactin. After 20 min centrifugation at $6000 \mathrm{xg}$ to remove any particulate matter, three $20 \mathrm{ml}$ samples with surfactin were each acidified to a $\mathrm{pH}$ of 2.0. Three samples of medium without surfactin were treated similarly. All samples were refrigerated overnight after acidification and then centrifuged as above to collect the precipitate. Each precipitate was extracted by adding two $\mathrm{ml}$ of methanol to the precipitate and hand shaking for one minute. A $1.0 \mathrm{ml}$ sample of the methanol solution was centrifuged for $3 \mathrm{~min}$ on a micro-centrifuge at $13,000 \mathrm{xg}$. The remaining volume was stored. Each sample was then analyzed on the HPLC (described below) for the presence of surfactin.

The JF-2 biosurfactant was quantified by high performance liquid chromatography (HPLC). A C18 column was used with a mobile phase of $70 \%$ methanol and 30\% $10 \mathrm{mM}$ phosphate buffer. The HPLC was run at a flow rate of $1 \mathrm{ml} / \mathrm{min}$ and the injection volume was $20 \mu \mathrm{l}$. An ultra violet detector was used with the wavelength set at $210 \mathrm{~nm}$. Samples for HPLC analysis were prepared as described above. 


\section{Results and Discussion}

\section{Growth Experiments}

Table 5 shows the growth rates of B. mojavensis JF-2 obtained with the addition of various carbon sources to the medium. This data indicate that the use of glucose gave the fastest growth rate under anaerobic conditions. The fastest growth rate occurred when the glucose concentration was $77 \mathrm{mM}$. However, the growth rate did not change dramatically over a range of 11 to $99 \mathrm{mM}$ glucose. Glucose may not be practical for MEOR fieldwork so other sources of sugar were tested to determine what commercial sources might be useful. Corn syrup derivatives were potential candidates for this purpose and previous experiments have shown that JF-2 would grow anaerobically on corn syrup; Maltrin was the corn syrup derivative used. The use of all three Maltrin types, M180, M200, M250, resulted in slower growth rates than that obtained using glucose as the carbon source. However, two, M180 and M200 gave very slow growth rates, about 10 to 12 times slower than glucose. Maltrin M250 did support a growth rate similar to that of glucose ( 0.10 opposed to a range of 0.10 to 0.17$) \mathrm{M} 250$ has a higher solubility and a higher percentage of monosaccharides than the other two Maltrins. Although all three corn syrups have a similar disaccharide composition (M180 5.8\%; M200 7.4\%; M250 6.9\%) they do differ significantly in the percentage of monosaccharides (M180 1.3\%; M200 2.3\%; M250 7.6\%). The Maltrin experiment suggests a preference for monosaccharide carbon sources over disaccharides or polysaccharides. This might suggest that corn syrup derivative containing a high percentage of monosaccharides would be a good substrate for field applications (M250).

Table 6 shows the relative growth yield (dry weight) for JF-2 when grown on four different sugars under anaerobic conditions. Growth with fructose produced the best growth yield at $73.7 \mathrm{~g}$ dry weight/mole substrate. Growth with 
glucose was next highest, while growth with sucrose and lactose produced similar growth yields near $31 \mathrm{~g}$ dry weight/mole substrate.

\section{Percent Recovery of Biosurfactant}

In order to quantify biosurfactant production accurately, it is necessary to concentrate the biosurfactant with an extraction procedure as described in the methods section. However, it is not clear how efficient this procedure is in recovering biosurfactant. This was tested using a known amount of biosurfactant as the standard. A test of extraction efficiency was performed to determine the degree to which biosurfactant is recovered from the growth medium. As can be seen in Table 7, the average percent recovery of surfactin from medium was about $70 \%$. The recovery was very similar in all three samples containing surfactin. Thus this value can be used as a correction factor to quantify the amount of biosurfactant in the medium. (The corrected concentration of biosurfactant will equal the measured concentration divided by 0.70 .) This was used as a correction factor to determine the actual amount present in the medium.

The effect of medium additions on biosurfactant production

Along with enhancing growth under anaerobic conditions, the presence of

Proteose peptone \#2 (PP2) in the medium also led to increased biosurfactant production. The biosurfactant was present after extended incubation suggesting either that the production of biosurfactant is not limited to the exponential phase of growth or that biosurfactant produced during exponential phase was stable for a long period of time. We have been unable as yet to determine exactly when biosurfactant is maximally produced. However, we do know that within the first 48 hours of incubation, growth is extensive but little biosurfactant appears to be produced. Both surface tension data and HPLC analysis failed to detect significant amounts of biosurfactant during this period. However, after 18 days, a significant amount was detected in the culture supernatant of medium containing 
PP2 (Table 8). Interestingly, the culture grown without PP2 used almost the same amount of sucrose that the culture growing with PP2, but did not produce a detectable amount of biosurfactant (Table 8).

\section{Conclusions}

Growth with glucose gave the fastest growth rate for Bacillus mojavensis JF-2 (JF-2) and monosaccharides were preferred over disaccharides as substrates for growth. The fastest growth rate occurred with a glucose concentration of 77 $\mathrm{mM}$. Although glucose gave the fastest growth rate, fructose gave the highest growth yield. The reason for this is not known at this time. The sample preparation steps used for high performance liquid chromatography (HPLC) analysis resulted in a biosurfactant recovery (from culture supernatant) of about $70 \%$. This provides us with a correction factor to quantify the biosurfactant concentration in the media. The presence of Proteose peptone \#2 (PP2) in the medium not only allows for better growth under anaerobic conditions but also led to increased biosurfactant production under anaerobic conditions. At this time, a medium containing PP2 and a monosaccharides source of sugars is best for anaerobic biosurfactant production 


\section{References}

1. M. Javaheri. 1985. Anaerobic production of a Biosurfactant by Bacillus licheniformis Strain JF-2: Purification and Properties of the Biosurfactant. Masters Thesis. University of Oklahoma.

2. M. J. McInerney, M. Javaheri and D. P. Nagle. 1990. Properties of the Biosurfactant Produced by Bacillus licheniformis strain JF-2. J.Ind.Micro. 5: $95-102$.

3. G.Jenneman; M.McInerney; R.Knapp; J.Clark; J.Feero; D.Revus; D.Menzie. 1983. A Halotolerant, Biosurfactant-producing Bacillus species Potentially Useful for Enhance Oil Recovery. Dev.Ind.Micro. 24: 485492.

4. J.Clark; D.Munnecke; G.Jenneman. 1981. In Situ Microbial Enhancement of Oil Production. Dev.Ind.Micro. 22: 695-701.

5. S. Lin; K. Carswell; M. Sharma. 1994. Continuous Production of the Lipopeptide Biosurfactant of Bacillus licheniformis JF-2. Appl. Microbiol. Biotechnol. 41: 281-285.

6. E. Wolin; M. Wolin; R. Wolfe. 1963. Formation of methane by bacterial Extracts. J. Bio. Chem. 238: 2882-2886.

7. W. Balch and R. S. Wolfe. 1976. New Approach to the Cultivation of Methanogenic Bacteria: 2-mercaptoethanesulfonic acid (HS-CoM)dependent Growth of Methanobacterium ruminantium in a Pressurized Atmosphere. Appl. Environ. Microbiol. 32: 781-791. 
8. P. Gerhardt, R. G. E. Murray, R. N. Costilow, E. W. Nester, W. A. Wood, N. R. Krieg, and G. B. Phillips. 1981. Manual of methods for general bacteriology. American Society for Microbiology, Washington, D. C. 
Table 5. The effect of different carbohydrates on the growth rate of JF-2 in $\mathrm{ME}_{2}$. The molarity of the Maltrin sugars was calculated assuming an average molecular weight equal to glucose.

\begin{tabular}{ccc}
\hline Substrate & Substrate Concentration $(\mathrm{mM})$ & Growth Rate $\left(\mathrm{hr}^{-1}\right)$ \\
\hline Glucose & 0 & 0.03 \\
Glucose & 11 & 0.13 \\
Glucose & 22 & 0.13 \\
Glucose & 33 & 0.14 \\
Glucose & 44 & 0.12 \\
Glucose & 55 & 0.12 \\
Glucose & 66 & 0.10 \\
Glucose & 77 & 0.17 \\
Glucose & 88 & 0.16 \\
Glucose & 99 & 0.15 \\
Maltrin M180 & 55 & 0.01 \\
Maltrin M200 & 55 & 0.01 \\
Maltrin M250 & 55 & 0.10 \\
Sorbose & 55 & -0.08 \\
Starch & 55 & 0.05 \\
Raffinose & 55 & 0.07 \\
\hline
\end{tabular}


Table 6. Molar growth yields of JF-2 with different carbohydrates.

\begin{tabular}{ccc}
\hline Substrate & $\begin{array}{c}\text { Substrate Concentration } \\
(\mathrm{mM})\end{array}$ & Growth Yield (g dry weight/mole substrate) \\
\hline Glucose & 20 & 36.8 \\
Sucrose & 20 & 31.5 \\
Fructose & 20 & 73.7 \\
Lactose & 20 & 30.5 \\
\hline
\end{tabular}


Table 7. The amount of surfactin recovered by acid precipitation and methanol extraction in three replicate twenty-ml samples

\begin{tabular}{cccc}
\hline Sample & $\begin{array}{c}\text { Initial amount } \\
\text { (grams) }\end{array}$ & $\begin{array}{c}\text { Amount recovered } \\
\text { (grams) }\end{array}$ & Percent Recovery \\
\hline $\mathbf{1}$ & 1.09 & 0.71 & 65 \\
$\mathbf{2}$ & 1.09 & 0.77 & 71 \\
$\mathbf{3}$ & 1.09 & 0.73 & 68 \\
\hline
\end{tabular}


Table 8. Biosurfactant production by JF-2 with and without Proteose peptone 2 added to the medium after 18 days of incubation under anaerobic conditions.

\begin{tabular}{|c|c|c|c|c|}
\hline $\begin{array}{l}\text { Proteose } \\
\text { Peptone } \\
\text { Added }\end{array}$ & $\begin{array}{c}\text { Biosurfactant } \\
\text { Sample } 1 \\
(\mathrm{mg} / \mathrm{ml})\end{array}$ & $\begin{array}{l}\text { Surface } \\
\text { Tension } \\
(\mathrm{mN} / \mathrm{M})\end{array}$ & $\begin{array}{c}\text { Yield } \\
\text { (mg } \\
\text { biosurfactant/ } \\
\text { mmol of } \\
\text { sucrose })\end{array}$ & $\begin{array}{l}\text { Amount of } \\
\text { sucrose } \\
\text { consumed } \\
(\mathrm{mmol})\end{array}$ \\
\hline Yes & 0.064 & 44 & 0.00372 & 15 \\
\hline No & $\mathrm{ND}^{\mathrm{a}}$ & 58 & ND & 17 \\
\hline $\begin{array}{c}\text { Yes } \\
\text { uninoculated }\end{array}$ & ND & 66 & ND & ND \\
\hline
\end{tabular}

${ }^{a} \mathrm{ND}$, not determined 